Вищий державний навчальний заклад Украӥни

“Буковинський державний медичний університет”, м. Чернівці

\title{
СИМУЛЯЦЙНІ ТЕХНОЛОГІЇ НАВЧАННЯ ПРИ ВИВЧЕННІ ПРОПЕДЕВТИКИ ВНУТРІШНІХ ХВОРОБ
}

\author{
Higher State Educational Establishment of Ukraine \\ "Bukovynian State Medical University”, Chernivtsi
SIMULATION LEARNING TECHNOLOGIES DURING STUDY PROPAEDEUTIC OF INTERNAL DISEASES

T. O. Ilashchuk, L. V. Mikulets

\begin{abstract}
Мета роботи - оцінити ефективність проведення навчальних симуляційних тренінгів на практичних заняттях із дисципліни “Пропедевтика внутрішніх хвороб” у студентів III курсу зі спеціальності “Лікувальна справа” у підвищенні якості освітнього процесу.

Основна частина. Відпрацювання практичних навичок на тренажері дає можливість студентам краще оволодіти методиками, зокрема можливість повторення і відпрацювання іiї до автоматизму. Також збільшуються можливості викладача як проконтролювати певний навик, так і доповнити його елементами ускладнення: поєднувати норму з патологією (наприклад: норма серцево-судинна система, патологія зі сторони системи органів дихання), а також поєднувати різну патологію даних систем.

Висновки. Симуляційне навчання доповнює підготовку студентів до реальної клінічної практики. Крім того, воно забезпечує контроль викладача за якістю виконання кожним студентом практичних навичок і також сприяє формуванню у студентів професійної компетентності.
\end{abstract}

Ключові слова: симуляційне навчання; пропедевтика внутрішніх хвороб; студенти.

The aim of the study - to evaluate the effectiveness of conducting stimulation training courses during practical classes of subject "Propaedeutic of Internal Diseases" with $3^{\text {rd }}$ year students of the "Medicine" specialty, to improve the quality of the educational process.

The main body. Practical skills improvement on the simulator enables students to learn with the help of better methods, including the possibility of repetition and working to automatism. There are increasing opportunities when teacher is able to control certain skills, and complement its complications elements, combined with pathology normal (e.g. normal - on the cardiovascular system and pathology on the part of the respiratory system) and to combine different pathologies of these systems.

Conclusion. Simulation training complements the training of students to real clinical practice. In addition, it provides control of the teacher for quality performance of each student practical skills and also contributes to the each student's professional competence.

Key words: simulation training; propaedeutic internal diseases; students.

Вступ. Реформування вищої медичної освіти вимагає пошуку нових методик для підготовки студентів, які були би професійно компетентними по закінченні вузу. В Україні в останні роки все більшого поширення набуває симуляційне навчання, слідуючи світовим тенденціям і керуючись Законом України “Про вищу освіту” від 01.07.2014 року № 1556-VII, а також як один із шляхів створення i впровадження нових конкурентоспроможних технологій для забезпечення інноваційного розвитку суспільства та підготовки фахівців інноваційного типу.

Отримано численні докази, які свідчать про успішний перенос набутих лікарем навичок роботи на лікування пацієнта [1-4], що не могло не привести до інтенсивного розвитку симуляційних

(c) Т. О. Ілащук, Л. В. Мікулець центрів. 32003 до 2008 року в США різко зросла кількість резидентур, де використовувалось симуляційне навчання лікарів, які спеціалізуються з невідкладної медицини, зокрема у 2003 році симуляційне навчання існувало у 33 (29 \%) резидентурах із 134 опитаних, а у 2008 році - у 114 (85\%) [5].

Історія сучасного симуляційного навчання починається з початку XX століття, коли в 1909 році в авіації був вперше застосований тренажер для відпрацювання навиків управління літаками Антуанета. В 1929 році американський інженер Едвін Лінк запатентував тренажер для навчання пілотів польотів по радіопеленгу.

У медицині історія симуляційного навчання має своє коріння ще в глибокій давнині і йде крок у крок із розвитком медичної науки. Першими фантома- 
ми, які дійшли і до сьогодні, є фантоми для пологів XVIII століття Анжеліки де Кюдре, яка придумала власну методику симуляційного тренінгу для повитух. Пітер Сафар, засновник серцево-легеневої реанімації, на той час завідувач відділення реанімації в Baltimore City Hospital, США, в 1957 році опублікував книгу “АВС of Resuscitation”, де були представлені основи СЛР (серцево-легеневої реанімації), що стали революційними в принципах надання невідкладної допомоги (потрійний прийом Сафарі). Це надихнуло норвезького лікаря Бьйорна Лінда та підприємця Асмунда Лаердала до створення першого манекена для проведення СЛР, який відомий нам як Resusci Anne (повернена до життя Анна). Перший комп’ютерний манекен спроектували інженер Стефан Абрахамсон і лікар Джадсон Денсон в Університеті Південної Каліфорнії в середині 60-х років [6]. Саме з цього часу починається історія симуляційного навчання у медицині. Розвиток комп’ютерної техніки та мікроелектроніки привів до появи високотехнологічних манекенів, які дозволяли би розкрити справжній потенціал симуляційного навчання. У зв’язку з цим у 1994 році було створено Європейську асоціацію з симуляції у медицині - SESAM, яка є ініціатором проведення щорічних міжнародних конференцій [7].

Теоретичні основи симуляційного, як одного 3 методів інтерактивного навчання в медицині, сформулював професор Гарвардської школи медицини Девід Габа. Він визначив симуляцію - технікою (методом), що направлена на зміну чи розширення реального досвіду за допомогою керованого на основі моделювання різних аспектів реального світу в інтерактивному режимі [8].

Мета роботи - оцінити ефективність проведення навчальних симуляційних тренінгів на практичних заняттях із дисципліни “Пропедевтика внутрішніх хвороб” у студентів III курсу зі спеціальності “Лікувальна справа” у підвищенні якості освітнього процесу.

Основна частина. Засвоєння і вдосконалення практичних навичок у підготовці студентів-медиків $є$ важливою умовою для забезпечення якісної професійної компетенції. При вивченні клінічних дисциплін, на жаль, виникають деякі труднощі для виконання і засвоєння практичних навичок: а) не завжди здійснюється повноцінний розбір кожного пацієнта, який був відібраний для курації; б) відсутність пацієнта по темі заняття; в) залежність від стану пацієнта (емоційного та загального); г) обмеженість у часі (група із 10-12 студентів за короткий час мають вислухати (аускультативно) па- цієнта). Це не дає студентам достатньо запам’ ятати аускультативну картину; д) викладач не може повністю проконтролювати, наскільки студент оволодів певною практичною навичкою (наприклад аускультація).

Поява можливості в організації симуляційного навчання - необхідний і розумний напрямок у навчальному процесі. На це необхідно акцентувати увагу, вже починаючи з перших курсів, а не тільки для окремих груп лікарів-ординаторів та інтернів.

На кафедрі пропедевтики ВДНЗУ “Буковинський державний медичний університет”, крім інтерактивних методів навчання [9, 10], студенти III курсу зі спеціальності “Лікувальна справа” мають можливість відпрацьовувати свої практичні навички на аускультаційному тренажері зі стетоскопом. Симулятор досконало відтворює фізіологію людини, що надає можливість аускультації серцевих тонів, як у нормі, так і при різних станах, а також дихальних шумів: фізіологічних та патологічних. Студент повинен пальпувати для визначення правильної аускультаційної зони і чутиме різні серцеві та легеневі звуки завдяки стетоскопу, переміщуючи його по моделі. Симулятор має 6 серцевих ділянок та 5 легеневих на передній поверхні, а також 10 різних ділянок на задній і 2 підпахвинні зони.

Відпрацювання практичних навичок на тренажері дає можливість студентам краще оволодіти методиками, зокрема можливість повторення і відпрацювання їі до автоматизму. Також збільшуються можливості викладача як проконтролювати певний навик, так і доповнити його елементами ускладнення: поєднувати норму з патологією (наприклад: норма - серцево-судинна система, патологія зі сторони системи органів дихання), а також поєднувати різну патологію даних систем.

Після відпрацювання практичних навичок на тренажері студенти краще орієнтуються в аускультативній картині не тільки на симуляторі, але і на пацієнтах. Якщо комусь із студентів все ж таки не вдається запам'ятати звукові феномени, вони мають можливість повторного вислуховування на тренажері, поки не запам'ятають, а потім вже вислуховують на пацієнтах.

Виживання знань студентів викладач перевіряє, шляхом виставлення будь-якої аускультативної картини, при цьому студент, вислухавши, має вказати що він почув. В окремих групах цей показник становив - 100 \%, а в середньому - 70-90 \%.

Висновки. Таким чином, симуляційне навчання доповнює підготовку студентів до реальної клініч- 
ної практики. Крім того, воно забезпечує контроль викладача за якістю виконання кожним студентом практичних навичок і також сприяє формуванню у студентів професійної компетентності.

J. B. Cooper, V. R. Taqueti // Qual Saf Health Care. 2004. - № 13 (Suppl 1). - P. 11-18.

7. Society in Europe for Simulation Applied to Medicine [Електронний ресурс]. - Режим доступу : http://www. sesam-web.org.

8. Gaba D. M. The future vision of simulation in healthcare / D. M. Gaba // Quality and Saferyin Health Care.- 2004. № 13 (Suppl. 1). - P. 2-10.

9. Ilashchuk T. O. Teaching Medical Students on the Base of a Competence Approach / T. O. Ilashchuk, L. V. Mikulets, Y. V. Tovkach // Deutschaftliche Wissenschaftsherold German Science Herald. - 2016. - № 4. - P. 42-44.

10. Мікулець Л. В. Впровадження інноваційних освітніх технологій в навчально-педагогічний процес на кафедрі пропедевтики внутрішніх хвороб Буковинського державного медичного університету / Л. В. Мікулець // Реалізація Закону України “Про вищу освіту” у вищій медичній та фармацевтичній освіті України” : матеріали Всеукр. навч.-наук. конф. $з$ міжнар. участю, присвяченої пам'яті ректора чл.-кор. НАМН України, проф. Л. Я. Ковальчука (з дистанційним під’єднанням ВМ(Ф)НЗ України за допомогою відеоконференц-зв'язку) (Тернопіль, 21-22 трав. 2015 р.). - Тернопіль : ТДМУ, 2015. - С. 349-350.

7. Society in Europe for Simulation Applied to Medicine. Retrieved from http://www.sesam-web.org.

8. Gaba, D.M. (2004). The Future vision of simulation in healthcare. Quality and Safety in Health Care, 13, 2-10.

9. Ilashchuk, T.O., Mikulets, L.V., \& Tovkach, Y.V. (2016). Teaching Medical Students on the Base of a Competence Approach. Deutschaftliche Wissenschaftsherold, 4, 42-44.

10. Mikulets, L.V. (2015). Vprovadzhennia innovatsiinykh osvitnikh tekhnolohii v navchalno-pedahohichnii protses na kafedri propedevtyky vnutrishnikh khvorob Bukovynskoho derzhavnoho medychnoho universytetu [Introduction of innovative educational technologies in the educational and pedagogical process at the department of Propedeutics of Internal Diseases of Bukovinian State Medical University]. Proceedings from RHEAU'15: Vseukrainska navchalnonaukova konferentsiia "Realizatsiia Zakonu Ukrainy "Pro vyshchu osvitu" u vyshchii medychnii ta farmatsevtychnii osviti Ukrainy (z dystantsiinym pidiednanniam VM(F)NZ Ukrainy za dopomohoiu videokonferents-zviazku)" - AllUkrainian educational and scientific conference "The Higher Education Act of Ukraine Implementation in Higher Medical Education of Ukraine (with remote connection $H M(P h) E I$ with videoconferencing)”. (pp. 349-350). Ternopil: TDMU [in Ukrainian]. development of mannequin simulators for clinical education and training. Postgraduate medical journal, 84(997), 563-570. 